Огляди літератури, оригінальні дослідження, погляд на проблему, ювілеї

УДК 616.24-002-092:612.017.1]-092.9:615.274

DOI 10.11603/1811-2471.2018.v0.i2.8471

\title{
ВПЛИВ КОРВІТИНУ НА ПОКАЗНИКИ ГУМОРАЛЬНОГО ІМУНІТЕТУ ЗА УМОВИ РОЗВИТКУ ЕКСПЕРИМЕНТАЛЬНОÏ ПНЕВМОНІї
}

๑О. О. Чугай

\section{Львівський національний медичний університет імені Данила Галицького}

РЕзЮМЕ. Специфічна імунна відповідь дуже важлива для захисту легень від патогенних мікроорганізмів, що зазнали розладу фагоцитозу (мікобактерій, грибів, вірусів), та позаклітинних організмів, які досить стійкі до фагоцитозу (інкапсульовані бактерії). Мікробні інфекції, які уникають природних захисних механізмів, виробляють значну кількість антигенів, що призводить до розвитку антиген-специфічної імунної відповіді. Зокрема, прикладом $є$ антиген-специфічна проліферація та диференціація В-лімфоцитів.

На сьогодні біофлавоноїди часто використовують в якості супровідної терапії для виправлення порушень, викликаних тривалим запальним процесом. Флавоноїди мають антиоксидантні, мембранозахисні, ангіопротективні, протизапальні, імуномодулюючі властивості.

Мета - дослідити вплив корвітину на показники клітинно-опосередкованого та гуморального імунітету при розвитку експериментальних пневмоній (ЕП).

Матеріал і методи. Експериментальне дослідження проводили на 30 морських свинках (самцях) вагою 180220 г, яких було поділено на 2 групи по 15 тварин у кожній:

І група - морські свинки з ЕП на 20 день;

II група - морські свинки, у яких застосовували корвітин.

Цей антиоксидант вводили в дозі 40 мг/кг внутрішньочеревно протягом 7 днів (з 13 до 20 дня).

Експериментальна пневмонія була індукована інтраназальним введенням тваринам культури Staphylococcus aureus методом В. Н. Шляпнікова та співавторів. Тварини були декапітовані на 20 день розвитку ЕП. Кількість Т- та В-лімфоцитів у крові визначали методом Е. Ф. Чернушенко, Л. С. Когосова. Рівень циркулюючих імунних комплексів визначали методом В. Хаскова, Я. Касліка.

Отримані результати статистично оцінювали за допомогою t-критерію Стьюдента.

Результати. Деякі принципи були виявлені після проведеної терапії. Зокрема, рівні В-лімфоцитів та ЦІК достовірно знизилися на 26,34 \% та 17,54 \% (р<0,05) відповідно, порівняно з показниками морських свинок на 20 день без лікування. Таким чином, введення препарату "Корвітин" мало профілактичний ефект у зв'язку з подальшим формуванням дисбалансу імунної відповіді, що підтвердило його протизапальну та імуномодулюючу дію.

Висновки. Препарат "Корвітин" запобігає подальшому розвитку дисбалансу імунної системи, обмежуючи запальні реакції. Цей ефект може бути викликаний протизапальними та імуномодулюючими властивостями вказаного препарату. Корвітин може бути рекомендований у якості супровідної терапії при пневмонії.

КЛючОВІ СЛОВА: корвітин; пневмонія; імунна система.

Вступ. Специфічна імунна відповідь $є$ надзвичайно важливою для захисту легень від патогенів, які зазнали неповного фагоцитозу (мікобактерії, гриби, віруси) та позаклітинних організмів, які складно піддаються фагоцитозу (інкапсульовані бактерії). Мікробні інфекції, які уникають природних захисних механізмів, продукують значну кількість антигенів, що призводить до розвитку антигеноспецифічної імунної відповіді [1]. Зокрема, сюди відносять антигеноспецифічну проліферацію та диференціювання В-лімфоцитів.

На сьогоднішній день для корекції порушень, викликаних тривалим запальним процесом, у вигляді терапії супроводу часто використовують біофлавоноїди. Флавоноїди мають антиоксидантні, мембрано- та ангіопротекторні, протизапальні, імуномодулюючі властивості тощо [2].

Мета - вивчення впливу корвітину на показники гуморального імунітету за умов розвитку експериментальної пневмонії (ЕП).

Матеріал і методи дослідження. Експериментальні дослідження проводили на 30 мор- ських свинках (самцях) масою 180-220 г, які були поділені на 2 групи по 15 тварин у кожній:

І група - морські свинки з ЕП на 20 добу;

II група - морські свинки з ЕП, яким проводили корекцію корвітином.

Вказаний антиоксидант вводили в дозі 40 мг/кг внутрішньоочеревинно впродовж 7 днів (з 13 по 20 добу).

Відтворювали ЕП шляхом інтраназального введення тваринам культури Staphylococcus aureus за методом В. Н. Шляпникова і співавт. [3] Тварин декапітували на 20 добу розвитку ЕП. Визначали вміст В-лімфоцитів у крові за методом Е. Ф. Чернушенко, Л. С. Когосова [4]. Рівень циркулюючих імунних комплексів (ЦІК) визначали за методом V. Haskova, J. Kaslik [5].

Отримані результати статистично оцінювали з використанням Е-критерію Стьюдента.

Результати й обговорення. У результаті проведеної терапії виявили певні закономірності. 3окрема, рівні В-лімфоцитів і ЦІК вірогідно знизилися на $26,34 \%$ і $17,54 \%$ (р<0,05) відповідно, порів- 
Огляди літератури, оригінальні дослідження, погляд на проблему, ювілеї

няно з показниками морських свинок на 20 добу без лікування. Таким чином, введення препарату «Корвітин» продемонструвало превентивний ефект щодо подальшого формування дисбалансу імунної відповіді й підтвердило його протизапальний та імуномодулюючий ефекти.

\section{ЛІТЕРАТУРА}

1. Дранник Г. Л. Клиническая иммунология и алергология / Г. Л. Дранник. - К. : ООО «Полиграфплюс», 2010. -552 c.

2. Chen K. T cell-mediated host immune defenses in the lung / K. Chen, K. Kolls // Annu. Rev. Immunol. - 2013. No. 31. - P. 605-633.

3. Экспериментальные модели острых пневмоний, вызванных условно-патологическими бактериями и их ассоциацией : метод. указания / В. И. Шляп-
Висновки. Препарат «Корвітин» запобігає подальшому розвитку дисбалансу імунної системи, обмежуючи запальну відповідь. Цей ефект може бути зумовлений протизапальними та імуномодулюючими властивостями корвітину, що дозволяє рекомендувати його в якості терапії супроводу при пневмонії.

ников, Т. Л. Солодова, С. А. Степанов [та ін.]. - Саратов, 1988. -30 c.

4. Чернушенко Е. Ф. Иммунология и иммунопатология заболеваний легких / Е. Ф. Чернушенко, Л. С. Когосова. - К. : Здоров'я, 1981. - 208 с.

5. Haskova V. Novy zpusob stanoveni circulujicich imunokomplexy w lidskych serech / V. Haskova, J. Kaslik, M. Matejckava // Cas. Lek. Ces. 1977. - No. 116 (14). P. 436-437.

\section{REFERENCES}

1. Drannik, G.M. (2010). Klinicheskaya immunologiya i alergologiya [Clinical immunology and allergology]. OOO "Poligraf plyus" [in Ukrainian].

2. Chen, K., \& Kolls, K. (2013). T cell-mediated host immune defenses in the lung. Annu. Rev. Immunol., 31, 605633.

3. Shlapnikov, V.I., Solodova, T.L., \& Stepanova, S.A. (1988). Eksperimentalnyye modeli ostrykh pnevmoniy, vyzvannykh uslovno-patologicheskimi bakteriyami i ikh assotsiatsiyey: metod. ukazaniya [Experimental models of acute

pneumonia caused by opportunistic bacteria and their association: methodical guidelines]. Saratov [in Russian].

4. Chernushenko, E.F., \& Kogosova, L.S. (1981). Immunologiya i immunopatologiya zabolevaniy legkikh [Immunology and immunopathology of lungs diseases]. Kyiv: Zdorovia [in Russian].

5. Haskova, V., Kaslik, J., \& Matejckava, M. (1977). Novy zpusob stanoveni circulujici imunokomplexy w lidskych serech. Casopis Lekaru Ceskych, 116 (14), 436-437.

\section{ВЛИЯНИЕ КОРВИТИНА НА ИНДИКАТОРЫ ГУМОРАЛЬНОГО ИММУНИТЕТА ПРИ ЭКСПЕРИМЕНТАЛЬНОМ РАЗВИТИИ ПНЕВМОНИИ}

\section{Львовский национальный медицинский университет имени Данила Галицкого}

РЕЗЮМЕ. Специфический иммунный ответ очень важен для защиты легких от патогенов, которые претерпели фрустрированный фагоцитоз (микобактерии, грибы, вирусы), и внеклеточных организмов, которые довольно устойчивы к фагоцитозу (инкапсулированные бактерии). Микробные инфекции, которые избегают естественных защитных механизмов, вызывают значительное количество антигенов, что приводит к развитию антигенспецифического иммунного ответа. В частности, примерами являются антигенспецифическая пролиферация и дифференцировка В-лимфоцитов.

В настоящее время биофлавоноиды часто используют в качестве сопутствующей терапии для коррекции нарушений, вызванных длительным воспалительным процессом. Флавоноиды обладают антиоксидантными, мембранозащитными, ангиопротективными, противовоспалительными, иммуномодулирующими свойствами и т. д.

Цель - изучить влияние корвитина на показатели клеточноопосредованного и гуморального иммунитета при экспериментальной пневмонии (ЭП).

Материал и методы. Экспериментальное исследование было проведено на 30 морских свинках (самцы) весом 180-220 г, поделенных на 2 группы по 15 животных в каждой:

І группа - морские свинки с ЭП на 20 день;

II группа - морские свинки под действием корвитина.

Антиоксидант корвитин вводили в дозе 40 мг/кг внутрибрюшинно в течение 7 дней (с 13 по 20 день). 
Огляди літератури, оригінальні дослідження, погляд на проблему, ювілеї

Экспериментальная пневмония индуцировалась интраназальным введением культуры Staphylococcus aureus для животных по методу В. Н. Шляпникова и соавт. Животных обезглавили на 20 день моделирования ЭП. Количество Т- и В-лимфоцитов в крови определяли по методу Е. Ф. Чернушенко, Л. С. Когосова. Уровень циркулирующих иммунных комплексов определяли по методу В. Хаскова, Я. Каслика.

Полученные результаты были статистически оценены с использованием t-критерия Стьюдента.

Результаты. Определенные принципы были обнаружены после проведенной терапии. В частности, уровни В-лимфоцитов и ЦИК достоверно снижались на 26,34 \% и 17,54 \% (p<0,05) соответственно, по сравнению с показателями морских свинок на 20 день без лечения. Таким образом, введение лекарственного средства «Корвитин» имело профилактический эффект в отношении дальнейшего формирования дисбаланса иммунного ответа и подтвердило его противовоспалительные и иммуномодулирующие эффекты.

Выводы. Лекарственное средство «Корвитин» предотвращало дальнейшее развитие дисбаланса иммунной системы, ограничивая воспалительную реакцию. Этот эффект может быть вызван противовоспалительными и иммуномодулирующими свойствами препарата. Корвитин может быть рекомендован в качестве сопутствующей терапии при пневмонии.

КЛЮЧЕВЫЕ СЛОВА: корвитин; пневмония иммунная система.

\section{INFLUENCE OF CORVITIN ON HUMORAL IMMUNITY INDICES IN EXPERIMENTAL PNEUMONIA DEVELOPMENT}

\section{Danylo Halytskyi Lviv National Medical University}

๑O. O. Chuhay

SUMMARY. Specific immune response is very important for lung protection against pathogens, which underwent frustrated phagocytosis (mycobacteria, fungi, viruses) and extracellular organisms, which are rather resistant to phagocytosis (incapsulated bacteria). Microbial infections, which avoid natural protective mechanisms, produce a significant number of antigens, leading to the development of antigen-specific immune response. In particular, antigen-specific proliferation and differentiation of B-lymphocytes are the examples.

Currently, bioflavonoids are often used as an accompanying therapy to correct disturbances, induced by long-lasting inflammatory process. Flavonoids possess antioxidant, membrane-protective, angioprotective, anti-inflammatory, immunomodulating properties, etc.

The aim of the study - to investigate the influence of Corvitin on indices of cell-mediated and humoral immunity in experimental pneumonia development (EP).

Material and Methods. Experimental investigation was performed on 30 guinea pigs (males) weighing 180-220 g, divided into 2 groups, 15 animals in each:

I group - guinea pigs with EP on the 20th day;

II group - guinea pigs under the action of corvitin.

This antioxidant was introduced in the dose $40 \mathrm{mg} / \mathrm{kg}$ intraperitoneally for 7 days (from 13 to 20 day).

Experimental pneumonia was induced by intranasal introduction of Staphylococcus aureus culture to animals by the method of V. N. Shliapnikov and co-authors. The animals were decapitated on the 20th day of EP development. Amount of T- and B-lymphocytes in the blood was determined by the method of E. F. Chernushenko, L. S. Kohosova. The level of circulating immune complexes was determined by the method of V. Haskova, J. Kaslik.

The obtained results were statistically evaluated by Student's t-criterion.

Results. Certain principles were detected after performed therapy. In particular, levels of B-lymphocytes and CIC reliably decreased by $26.34 \%$ and $17.54 \%$ ( $p<0.05$ ), respectively, compared with the indices of guinea pigs on the 20 th day without treatment. Thus, introduction of Corvitin medication had a preventive effect in relation to further formation of immune response imbalance and confirmed its anti-inflammatory and immunomodulating effects.

Conclusions. Corvitin prevented further development of immune system imbalance, limiting inflammatory response. This effect may be caused by anti-inflammatory and immune-modulating properties of Corvitin which may be recommended as an accompanying therapy in pneumonia.

KEY WORDS: corvitin; pneumonia; immune system. 